\title{
FRACTIONAL CRYSTALLIZATION TESTING WITH INTERIM PRETREATMENT SYSTEM FEEDS
}

\author{
D. L. Herting \\ CH2M HILL Hanford Group, Inc. \\ Richland, WA 99352 \\ U.S. Department of Energy Contract DE-AC27-99RL14047
}

$\begin{array}{lll}\text { EDT/ECN: } & \text { DRF } & \text { UC: } \\ \text { Cost Center: } & 74 \mathrm{~A} 10 & \text { Charge Code: } \\ \text { B\&R Code: } & & \text { Total Pages: } 24\end{array}$

Key Words: fractional, crystallization, laboratory, testing, simulated, tank, waste, SST, DST, IPS, sodium hydroxide, sodium aluminate, thermodynamic, modeling, laboratory-scale, filtration, filter cake, turbidity, hydroxide concentration, metals, anions, crystal size distribution, boildown, data

Abstract: The fractional crystallization process was developed as a pretreatment method for saltcake waste retrieved from Hanford single-shell tanks (SST). The process separates the retrieved SST waste into a high-level waste stream containing the bulk of the radionuclides and a low-activity waste stream containing the bulk of the nonradioactive sodium salts. The Interim Pretreatment System project shifted the focus on pretreatment planning from SST waste to double-shell tank waste.

TRADEMARK DISCLAIMER. Reference herein to any specific commercial product, process, or service by trade name, trademark, manufacturer, or otherwise, does not necessarily constitute or imply its endorsement, recommendation, or favoring by the United States Government or any agency thereof or its contractors or subcontractors

Printed in the United States of America. To obtain copies of this document, contact: Document Control Services, P.O. Box 950, Mailstop H6-08, Richland WA 99352, Phone (509) 372-2420; Fax (509) 376-4989.
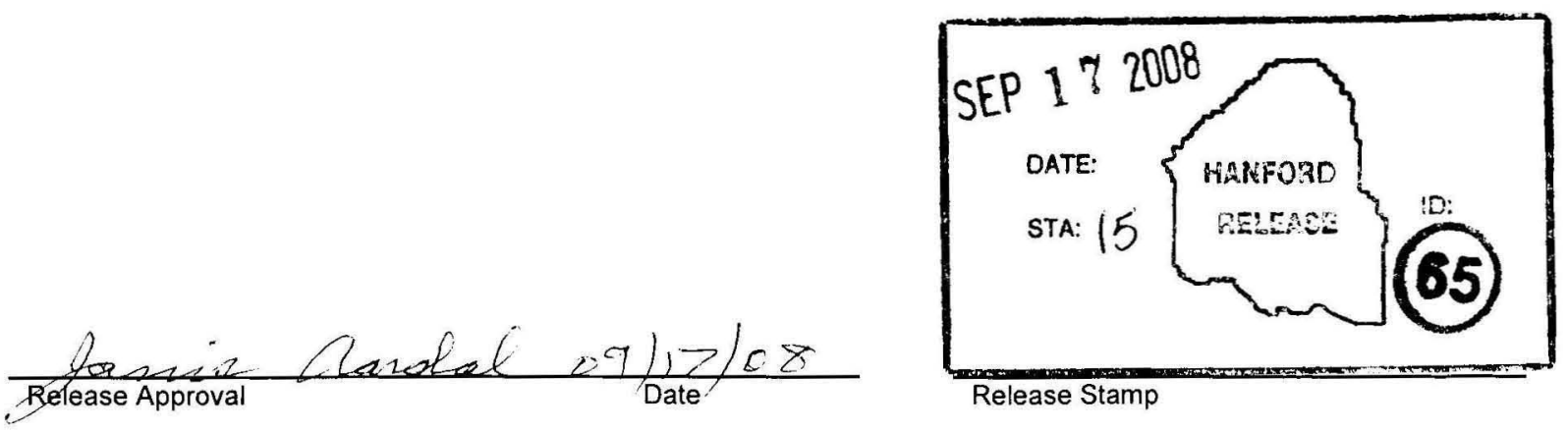

\section{Approved For Public Release}


RPP-RPT-38985

Revision 0

\title{
FRACTIONAL CRYSTALLIZATION TESTING WITH INTERIM PRETREATMENT SYSTEM FEEDS
}

\author{
D. L. Herting \\ R. J. Toth \\ M. S. Ulk \\ CH2M HILL Hanford Group, Inc.
}

Date Published

September 2008

\section{CH2WHILL \\ Hanford Group, Inc.}

Prepared for the U.S. Department of Energy

Office of River Protection

Contract No. DE-AC27-99RL14047 


\section{TABLE OF CONTENTS}

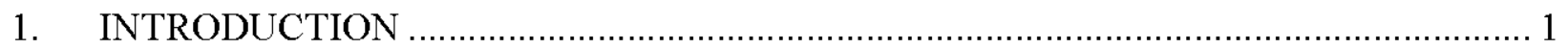

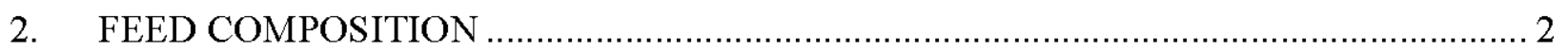

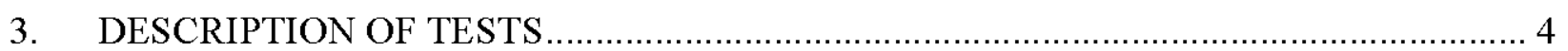

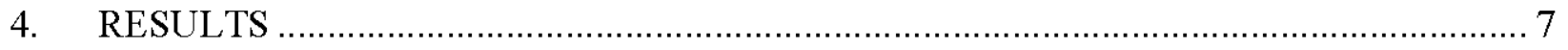

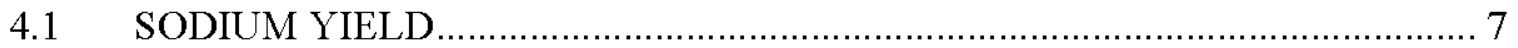

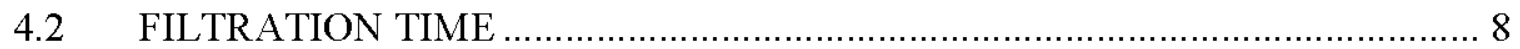

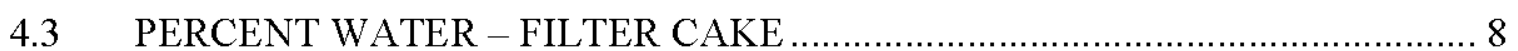

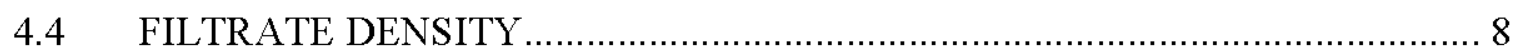

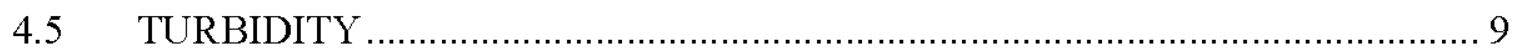

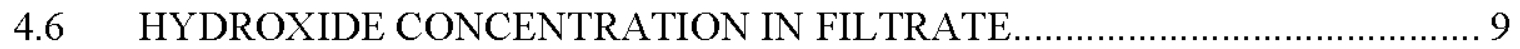

4.7 FILTRATE CONCENTRATIONS OF METALS AND ANIONS ..................... 10

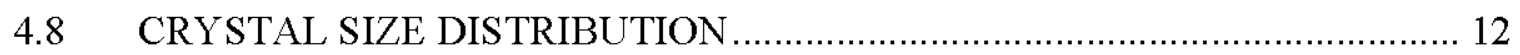

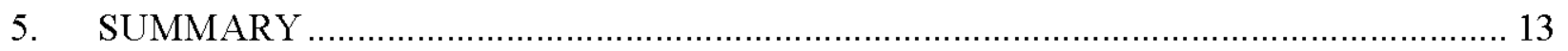

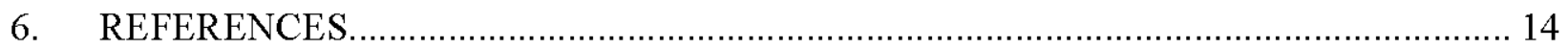

APPENDIX A Boildown Test Data................................................................................... A

\section{LIST OF FIGURES}

Figure 3-1. Temperature/Pressure Profile for Set B Group 4 Boildown. ................................ 4

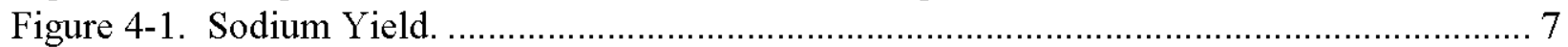

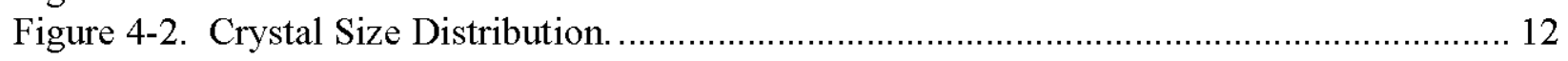

\section{LIST OF TABLES}

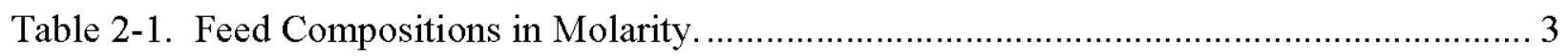

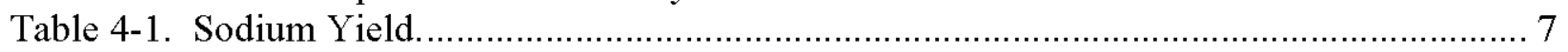

Table 4-2. Filtration Time (minutes). ....................................................................... 8

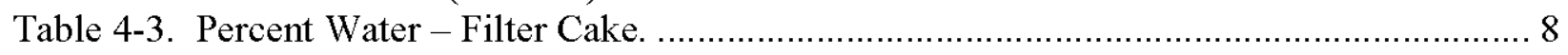

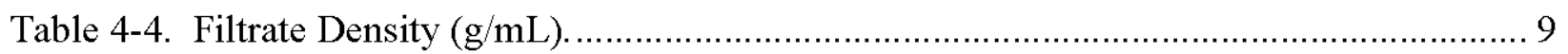

Table 4-5. Filter Cake Sample Turbidity (NTU) . .......................................................... 9

Table 4-6. Hydroxide Concentration in Filtrate (M) ...................................................... 10

Table 4-7. Filtrate Concentrations (molarity) of Metals and Anions....................................... 11

\section{ACRONYMS}

DST double-shell tank

IPS Interim Pretreatment System

$\mathrm{PN} \quad$ partial neutralization

PNO partial neutralization with oxidation

SST single-shell tank

TOC total organic carbon 


\section{INTRODUCTION}

The fractional crystallization process was developed as a pretreatment method for saltcake waste retrieved from Hanford single-shell tanks (SST). The process separates the retrieved SST waste into a high-level waste stream containing the bulk of the radionuclides and a low-activity waste stream containing the bulk of the nonradioactive sodium salts. Development work on the fractional crystallization project included the following:

a. Thermodynamic modeling (RPP-34455, Hanford Medium/Low Curie Waste Pretreatment Alternatives Project - Subtask 2.1 and Subtask 2.2).

b. Laboratory-scale testing with simulated tank waste (RPP-RPT-34136, Hanford Medium/Low Curie Waste Pretreatment Alternatives Project-Phase II, Subtask 2.5 and Subtask 2.6, and RPP-RPT-35261, Fractional Crystallization Laboratory Tests with Simulated Tank Waste).

c. Laboratory-scale testing with actual tank waste (RPP-RPT-31352, 2007, Fractional Crystallization Laboratory Tests with Actual Tank Waste).

d. Engineering-scale testing with simulated waste (RPP-RPT-33228, Hanford Medium/Low Curie Waste Pretreatment Alternatives Project-Phase II Report on Pre-Pilot Work at Swenson Technology, Inc.).

e. One-fifth-scale pilot plant operation with simulated waste (RPP-39091, Hanford Medium/Low Curie Waste Pretreatment Alternatives Project-Fractional Crystallization Pilot Scale Testing Final Report).

In all cases, fractional crystallization was shown to be a viable waste pretreatment process capable of meeting or exceeding the separation requirements.

In FY 2008, the Interim Pretreatment System (IPS) project shifted the focus on pretreatment planning from SST waste to double-shell tank (DST) waste. Double-shell tank waste is less attractive than SST waste for processing by fractional crystallization because it contains a higher percentage of "noncrystallizable" sodium salts, i.e., higher concentrations of sodium hydroxide and sodium aluminate. Therefore, additional laboratory-scale testing with simulated waste was conducted to evaluate the potential impacts on the ability of the fractional crystallization process to meet separation requirements with DST waste feed.

Results of the laboratory testing showed the following:

a. The physical behavior of the waste during evaporation was not adversely impacted by the change from SST feed to DST feed.

b. The efficiency of the solid/liquid separation was not adversely impacted, which implies that the decontamination factor was not adversely affected, though the decontamination factor was not measured directly.

c. The sodium yield (percentage of sodium reporting to the low-activity waste stream) was adversely impacted. Therefore, additional laboratory tests were performed to investigate methods for improving the sodium yield through partial neutralization (PN) and partial neutralization with oxidation (PNO). Those methods proved to be moderately successful. 


\section{FEED COMPOSITION}

The bulk of the development work on the fractional crystallization process, including the pilot plant operation, was based on a feed composition known as "SST Early." The IPS project, for planning purposes, identified the initial eight specific DST waste compositions that were expected to become feeds for the IPS facility whether that facility turned out to employ fractional crystallization, ion exchange, or caustic-side solvent extraction.

Initially there was a plan to operate the fractional crystallization pilot plant with some of the IPS feed solutions. Nearly 10,000 gal of SST Early feed simulant was already procured for operation of the pilot plant. Obviously, it was not cost-effective to prepare 10,000 gal of each of the eight IPS feed solutions, so a plan was developed to prepare four generic IPS feed simulants through judicious addition of chemicals to the SST Early simulant. These four generic simulants were referred to as IPS Group 1, Group 2, Group 3, and Group 4, where each simulant represented a group of IPS feed tanks with similar compositions. Table 2-1 shows the compositions of the SST Early, the eight individual IPS feed tanks, and the four generic IPS feed groups.

Note that all of the feed solutions in Table 2-1 are normalized to a constant Na concentration of $6.43 \mathrm{M}$. The eight IPS feed tanks were sorted and arranged into groups based on their $\mathrm{Al}$ and $\mathrm{OH}$ concentrations.

SST Early feed could be converted to Group 1 feed by the addition of $\mathrm{NaAlO}_{2}$ (sodium aluminate), $\mathrm{NaF}, \mathrm{KNO}_{2}, \mathrm{NaNO}_{2}, \mathrm{Na}_{2} \mathrm{C}_{2} \mathrm{O}_{4}$ (sodium oxalate), $\mathrm{NaC}_{2} \mathrm{H}_{3} \mathrm{O}_{2}$ (sodium acetate), $\mathrm{NaOH}$, and enough water to return the $\mathrm{Na}$ concentration to $6.43 \mathrm{M}$. The salt additions and subsequent dilution make it possible to match all of the Group 1 compositions to the group averages (the target concentrations) except for $\mathrm{F}$ and $\mathrm{Ox}$ (oxalate), which remain well below target. The reason they remain below target is that addition of more $\mathrm{NaF}$ and $\mathrm{Na}_{2} \mathrm{C}_{2} \mathrm{O}_{4}$ would result in $\mathrm{F}$ and $\mathrm{Ox}$ concentrations that are too high for the subsequent groups.

Group 1 feed could be converted to Group 2 feed by addition of $\mathrm{NaAlO}_{2}, \mathrm{NaCl}, \mathrm{NaNO}_{2}, \mathrm{NaOH}$, and water. The Group $2 \mathrm{Cr}$ concentration is unavoidably a little higher than the target, while the Ox and total organic carbon (TOC) concentrations are lower than target for the same reason as described for the $\mathrm{F}$ and $\mathrm{Ox}$ in Group 1.

Group 2 feed could be converted to Group 3 feed by addition of $\mathrm{NaAlO}_{2}, \mathrm{NaNO}_{2}, \mathrm{NaOH}$, and water. Group 2 concentrations of $\mathrm{F}, \mathrm{Ox}, \mathrm{PO}_{4}$, and $\mathrm{SO}_{4}$ are all somewhat higher than target, while $\mathrm{K}$ and TOC concentrations are lower, but all are relatively minor components.

Group 3 feed could be converted to Group 4 feed by addition of $\mathrm{NaAlO}_{2}, \mathrm{Na}_{2} \mathrm{CO}_{3}, \mathrm{NaOH}$, and water. Concentrations of $\mathrm{Cr}$ and $\mathrm{Ox}$ are higher than target, but both are very minor components.

Plans to test the IPS feed solutions in the pilot plant were never implemented, but laboratoryscale testing was performed with all four of the IPS group feed solutions. Results of those tests are presented in this report. 
Table 2-1. Feed Compositions in Molarity.

\begin{tabular}{|c|c|c|c|c|c|c|c|c|c|c|c|c|c|c|}
\hline Feed & Al & Cl & $\mathrm{Cr}$ & F & $\mathbf{K}$ & $\mathrm{Na}$ & $\mathrm{NO}_{2}$ & $\mathrm{NO}_{3}$ & $\mathbf{O x}$ & $\mathrm{PO}_{4}$ & $\mathrm{SO}_{4}$ & $\mathrm{CO}_{3}$ & TOC & $\mathrm{OH}$ \\
\hline SST Early & 0.289 & 0.073 & 0.019 & 0.010 & 0.018 & 6.43 & 0.515 & 3.276 & 0.006 & 0.046 & 0.128 & 0.614 & 0.012 & 0.618 \\
\hline AP-101 & 0.32 & 0.059 & 0.013 & 0.033 & 0.158 & 6.43 & 0.73 & 3.021 & 0.019 & 0.046 & 0.08 & 0.43 & 0.15 & 1.11 \\
\hline AP-107 & 0.33 & 0.063 & 0.016 & 0.031 & 0.080 & 6.43 & 0.98 & 2.499 & 0.025 & 0.042 & 0.13 & 0.52 & 0.17 & 1.03 \\
\hline Group 1 & 0.32 & 0.060 & 0.016 & 0.025 & 0.12 & 6.43 & 0.87 & 2.68 & 0.015 & 0.038 & 0.105 & 0.50 & 0.15 & 1.06 \\
\hline AP-104 & 0.45 & 0.100 & 0.010 & 0.025 & 0.125 & 6.43 & 1.03 & 2.548 & 0.021 & 0.051 & 0.05 & 0.39 & 0.25 & 1.20 \\
\hline AP-105 & 0.49 & 0.151 & 0.005 & 0.006 & 0.073 & 6.43 & 1.67 & 1.862 & 0.004 & 0.032 & 0.04 & 0.31 & 0.31 & 1.35 \\
\hline AP-103 & 0.58 & 0.116 & 0.010 & 0.028 & 0.102 & 6.43 & 1.44 & 1.884 & 0.030 & 0.043 & 0.04 & 0.47 & 0.44 & 1.03 \\
\hline Group 2 & 0.50 & 0.12 & 0.012 & 0.020 & 0.10 & 6.43 & 1.37 & 2.12 & 0.012 & 0.030 & 0.083 & 0.40 & 0.12 & 1.19 \\
\hline AP-108 & 0.62 & 0.101 & 0.011 & 0.014 & 0.187 & 6.43 & 1.25 & 2.035 & 0.005 & 0.014 & 0.03 & 0.39 & 0.21 & 1.56 \\
\hline AP-102 & 0.67 & 0.116 & 0.009 & 0.002 & 0.094 & 6.43 & 1.56 & 2.022 & 0.003 & 0.023 & 0.02 & 0.22 & 0.15 & 1.51 \\
\hline Group 3 & 0.64 & 0.10 & 0.010 & 0.017 & 0.08 & 6.43 & 1.40 & 1.80 & 0.010 & 0.025 & 0.070 & 0.34 & 0.10 & 1.53 \\
\hline AN-104 & 0.69 & 0.108 & 0.004 & 0.014 & 0.057 & 6.43 & 1.23 & 1.555 & 0.001 & 0.021 & 0.05 & 0.40 & 0.08 & 1.87 \\
\hline Group 4 & 0.69 & 0.09 & 0.009 & 0.015 & 0.07 & 6.43 & 1.20 & 1.54 & 0.009 & 0.022 & 0.060 & 0.40 & 0.09 & 1.87 \\
\hline
\end{tabular}




\section{DESCRIPTION OF TESTS}

Three sets of evaporation tests were performed:

a. Set A: Direct evaporation by the semicontinuous method with the Hanford boildown apparatus (see ATS-LT-519-183, "ATS Determination of Properties of Radiological Solutions as a Function of Volume Reduction at Reduced Pressure").

b. Set B: Evaporation accompanied by periodic additions of dilute $(3 \mathrm{M})$ nitric acid, a process referred to as $\mathrm{PN}$.

c. Set C: Evaporation accompanied by periodic additions of more concentrated $(8 \mathrm{M})$ nitric acid, a process referred to as PNO.

Each set consisted of one evaporation test with each of the four IPS feed groups. The basic procedure was held constant for all tests. Briefly, $100 \mathrm{~mL}$ of feed solution was placed in the boildown pot and $150 \mathrm{~mL}$ of feed solution was placed in a plastic bottle connected to the boildown pot by a vacuum siphon. The evaporation temperature was held constant at $50{ }^{\circ} \mathrm{C}$ by manually adjusting the pressure. (A typical temperature/pressure plot is shown in Figure 3-1.) Condensate was collected in a graduated cylinder. Each time the condensate volume increased by $10 \mathrm{~mL}$, a corresponding $10 \mathrm{~mL}$ of feed solution was added to the pot via the siphon. The evaporation endpoint was the point at which all of the feed was added to the pot and the apparent slurry viscosity indicated that the slurry contained approximately $30 \%$ undissolved solids. (The same visual endpoint determination was used for all 12 tests.) The final slurry was filtered by pouring the slurry from the boildown pot into a medium-frit glass filter. Vacuum was applied to the filter, and a stopwatch was used to measure the elapsed time from application of the vacuum until the filtrate collection rate became slower than $1 \mathrm{drop} / \mathrm{sec}$.

Figure 3-1. Temperature/Pressure Profile for Set B Group 4 Boildown.

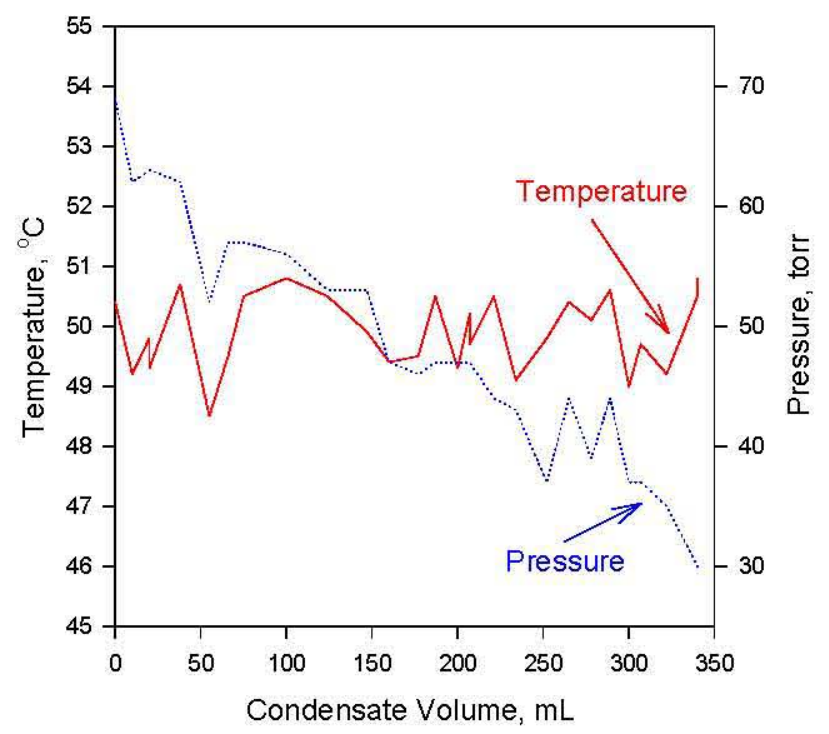


For the PN boildowns (Set B), feed additions were made after each $25-\mathrm{mL}$ increase in condensate volume. Each feed addition consisted of $10 \mathrm{~mL}$ of feed followed immediately by $5 \mathrm{~mL} \mathrm{H}_{2} \mathrm{O}, 5 \mathrm{~mL}$ of $3 \mathrm{M} \mathrm{HNO}_{3}$, and $5 \mathrm{~mL} \mathrm{H}_{2} \mathrm{O}$. The intent was to maximize mixing of the acid with the slurry in the pot and thus to minimize areas of locally high acid concentration in the pot.

For the PNO boildowns (Set C), the nitric acid concentration was increased to $8 \mathrm{M}$, and the $\mathrm{H}_{2} \mathrm{O}$ additions before and after the acid additions were eliminated. The intent was to drive oxidation of nitrite to nitrate to increase the relative amount of sodium nitrate in the final slurry.

Addition of nitric acid to the boildown pot during the evaporation can potentially result in a number of reactions ( $\mathrm{rx}$ ), including the following:

$$
\begin{aligned}
& \mathrm{HNO}_{3}+\mathrm{NaOH} \rightarrow \mathrm{NaNO}_{3}+\mathrm{H}_{2} \mathrm{O} \\
& 2 \mathrm{HNO}_{3}+\mathrm{Na}_{2} \mathrm{CO}_{3} \rightarrow 2 \mathrm{NaNO}_{3}+\mathrm{CO}_{2} \uparrow+\mathrm{H}_{2} \mathrm{O} \\
& \mathrm{HNO}_{3}+\mathrm{NaAl}(\mathrm{OH})_{4} \rightarrow \mathrm{NaNO}_{3}+\mathrm{Al}(\mathrm{OH})_{3} \downarrow+\mathrm{H}_{2} \mathrm{O} \\
& 2 \mathrm{HNO}_{3}+3 \mathrm{NaNO}_{2} \rightarrow 3 \mathrm{NaNO}_{3}+2 \mathrm{NO} \uparrow+\mathrm{H}_{2} \mathrm{O} \\
& 2 \mathrm{HNO}_{3}+2 \begin{array}{r}
\mathrm{Na}_{2} \mathrm{CrO}_{4}+3 \mathrm{NaNO}_{2}+3 \mathrm{H}_{2} \mathrm{O} \rightarrow 2 \mathrm{NaCr}(\mathrm{OH})_{4}+5 \mathrm{NaNO}_{3} \\
(\text { (gellow) }
\end{array}
\end{aligned}
$$

At infinite acid dilution and with perfect mixing, reaction 1 is the only reaction that takes place because $\mathrm{NaOH}$ is the strongest base in the system. The PN evaporations were performed in such a way as to maximize reaction 1 and minimize the other reactions. The PNO evaporations were intended to take advantage of the other reactions, especially reaction 4 .

Reaction 1 increases sodium yield by converting noncrystallizable $\mathrm{NaOH}$ to the preferred product salt, $\mathrm{NaNO}_{3}$.

Reaction 2 is favorable because $\mathrm{NaNO}_{3}$ crystals are larger and easier to separate from the mother liquor than are $\mathrm{Na}_{2} \mathrm{CO}_{3}$ crystals. The disadvantage of reaction 2 is that the evolution of the product gas $\left(\mathrm{CO}_{2}\right)$ can cause excessive foaming or bumping of the slurry in the boildown pot (or the evaporator body).

Reaction 3 produces the favorable $\mathrm{NaNO}_{3}$ salt but at the expense of precipitating aluminum hydroxide, which tends to form a gel when precipitated quickly by acid addition. Such a gel can cause significant solid/liquid separation problems, so reaction 3 is to be avoided. Several times during execution of the PN and PNO tests, a gel was observed to form at the surface of the slurry immediately after acid addition, but it invariably redissolved quickly with agitation.

Reaction 4 is favorable because it increases the amount of $\mathrm{NaNO}_{3}$ in the slurry but again suffers from the production of a gas (NO) that can cause excessive frothing or bumping. The NO gas is quickly oxidized to the poisonous brown gas $\mathrm{NO}_{2}$ in the vapor phase. This brown gas was seldom observed in the PN tests but was common during the PNO tests. The brown gas was quickly removed in all cases by the vacuum system but could be an environmental concern in an operating plant. 
Reaction 5, representing the reduction of chromium from $\mathrm{Cr}$ (VI) to $\mathrm{Cr}$ (III), was not predicted but was observed in all of the PNO tests. It was never observed in the PN tests. The color change from bright yellow to emerald green was dramatic during the PNO tests. The actual stoichiometry may differ from that shown in reaction 5. Based on experience, the reaction does not take place in alkaline solution but apparently proceeds rapidly in areas of local acidification. The actual reducing agent is likely $\mathrm{HNO}_{2}$ formed by acidification of the $\mathrm{NaNO}_{2}$.

For the PN set of tests, each acid addition was typically followed by an increase in frothing, but the degree of frothing was controllable, i.e., the level of froth never exceeded the head space of the boildown apparatus. The increased frothing suggests that reactions 2 and 4 were occurring to some small extent.

For the PNO set of tests, each acid addition was typically followed by a violent increase in frothing up into the condenser above the boildown pot. The frothing was most violent in the Group 1 PNO test in which the $8 \mathrm{M} \mathrm{HNO}_{3}$ was added in $10-\mathrm{mL}$ increments. The frothing was less violent but still relatively unmanageable in the Group 2-Group 4 PNO tests in which the $\mathrm{HNO}_{3}$ increments were reduced to $5 \mathrm{~mL}$ at a time. The violent frothing indicates that reactions 2 and 4 were occurring at a much higher rate in the PNO tests than in the PN tests, as planned. However, the violent frothing suggests that it might not be possible to implement this method in the actual fractional crystallization evaporator without making some engineering adjustments to the evaporator and offgas system designs.

Partial neutralization has been used at the Hanford 242-S evaporator (RHO-CD-1515, 242-S Evaporator Crystallizer Third Partial Neutralization Campaign) but is not currently used at the 242-A evaporator. 


\section{RESULTS}

Several measurements were made during and after each boildown test. The raw data are presented in Appendix A. The data are arranged here to examine the effects of increasing aluminate and hydroxide in the feed (running vertically in each data table) and the effects of increasing the amount and concentration of nitric acid (running left-to-right in each table).

\subsection{SODIUM YIELD}

One of the primary criteria for a viable pretreatment process for Hanford tank waste is that the process must deliver a low-activity waste stream containing greater than $50 \%$ of the sodium present in the feed stream, i.e., the Na Yield must be $>50 \%$. For feed solutions derived from SST saltcake waste (e.g., SST Early), achieving this criterion was never difficult because $\mathrm{NaNO}_{3}$ represented a large fraction of the total $\mathrm{Na}$ in the feed solution. The $\mathrm{Na}$ Yield for SST Early tests averaged approximately $75 \%$ in prior tests with simulated and actual SST Early.

For the IPS feed solutions derived from DSTs, the relative fraction of $\mathrm{NaNO}_{3}$ in the feed is considerably less (see Table 2-1), and the Na Yield suffers as a result, as shown in Table 4-1. The results in Table 4-1 also show that the Na Yield for all of the IPS feeds can be brought above the $50 \%$ minimum by employing PN or PNO. The data are plotted in Figure 4-1.

Table 4-1. Sodium Yield.

\begin{tabular}{|c|c|c|c|}
\hline IPS & Direct & PN & PNO \\
\hline Group 1 & 60.9 & 67.8 & 65.0 \\
\hline Group 2 & 49.1 & 48.8 & 64.7 \\
\hline Group 3 & 44.8 & 51.3 & 55.2 \\
\hline Group 4 & 48.2 & 52.7 & 56.3 \\
\hline
\end{tabular}

Figure 4-1. Sodium Yield.

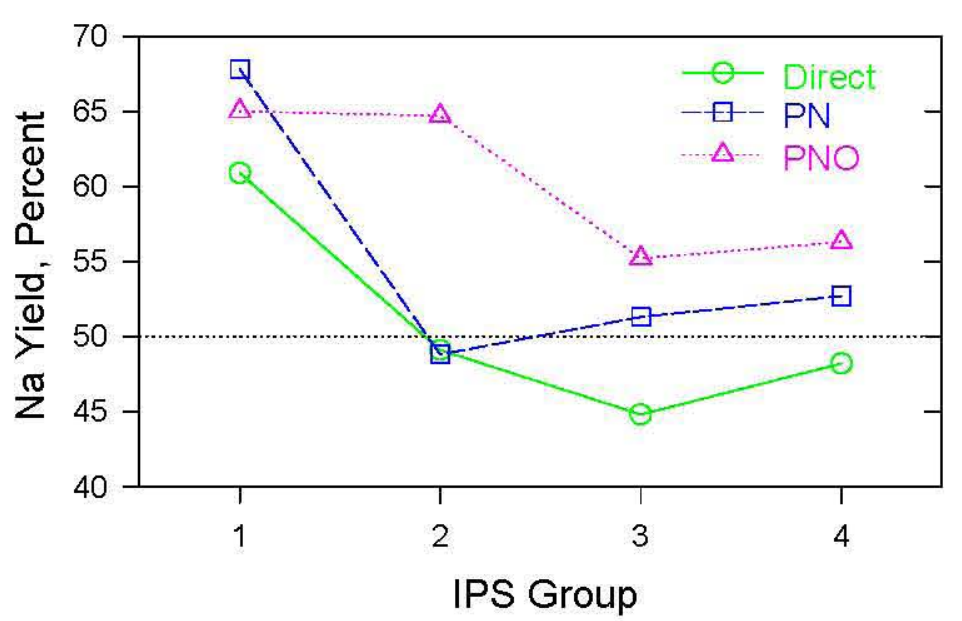




\subsection{FILTRATION TIME}

The length of time required to filter the product slurry has routinely been used as a rough indicator of the efficiency of the solid/liquid separation - the faster the filtration, the more complete the separation, and the better the radionuclide decontamination. For previous tests with SST Early feed, filtration times around 2 minutes were common. Results with the IPS feeds (Table 4-2) show that neither the feed composition nor the acid additions had any significant effect on the filtration times, which were adequate in all cases to provide good decontamination.

Table 4-2. Filtration Time (minutes).

\begin{tabular}{|c|c|c|c|}
\hline IPS & Direct & PN & PNO \\
\hline Group 1 & 1.93 & 2.25 & 2.10 \\
\hline Group 2 & 2.10 & 2.02 & 2.50 \\
\hline Group 3 & 2.07 & 2.08 & 1.43 \\
\hline Group 4 & 2.17 & 2.15 & 1.70 \\
\hline
\end{tabular}

\subsection{PERCENT WATER - FILTER CAKE}

Percent water in the filter cake provides another rough indicator of the efficiency of solid/liquid separation - the drier the filter cake, the better the separation and decontamination. Percent waters were determined by oven-drying of filter cake samples (see Table 4-3). Results indicate that separation suffers from increasing $\mathrm{Al}$ and $\mathrm{OH}$ concentrations (increasing from Group 1 to Group 4 for the direct evaporation samples) but can be improved through PN or PNO.

Table 4-3. Percent Water - Filter Cake.

\begin{tabular}{|c|c|c|c|}
\hline IPS & Direct & PN & PNO \\
\hline Group 1 & 13.1 & 13.9 & 11.1 \\
\hline Group 2 & 14.9 & 11.4 & 11.1 \\
\hline Group 3 & 15.9 & 11.5 & 13.0 \\
\hline Group 4 & 17.0 & 11.3 & 11.5 \\
\hline
\end{tabular}

\subsection{FILTRATE DENSITY}

The density of the filtrate solution is a rough indicator of the ionic strength of the liquid phase at the evaporation endpoint. Higher density indicates higher ionic strength, which is undesirable because the solutions are thermodynamically more unstable - more prone to post-filtration precipitation and downstream processing difficulties. The data trends shown in Table 4-4 are not surprising - that the filtrate density increases with increasing $\mathrm{Al}$ and $\mathrm{OH}$ (going down the columns) and decreases with increasing acid addition (left-to-right). 
Table 4-4. Filtrate Density (g/mL).

\begin{tabular}{|c|c|c|c|}
\hline IPS & Direct & PN & PNO \\
\hline Group 1 & 1.541 & 1.503 & 1.493 \\
\hline Group 2 & 1.549 & 1.533 & 1.518 \\
\hline Group 3 & 1.560 & 1.560 & 1.520 \\
\hline Group 4 & 1.599 & 1.556 & 1.516 \\
\hline
\end{tabular}

\subsection{TURBIDITY}

Precipitation of aluminum is generally avoided during fractional crystallization processing. Whether the aluminum precipitates as $\mathrm{Al}(\mathrm{OH})_{3}$ or as $\mathrm{NaAl}(\mathrm{OH})_{4}$, the crystals tend to be very small and difficult to filter. Some aluminum is always present in the filter cake in the form of residual liquor. Turbidity analysis provides a rough indication of the amount of aluminum in the filter cake as either residual liquor or precipitate or both. A sample of the filter cake is dissolved in water and adjusted to $\mathrm{pH} 8$ by addition of $\mathrm{HNO}_{3}$. The turbidity of the resulting solution is due mainly to the presence of $\mathrm{Al}(\mathrm{OH})_{3}$, regardless of whether the source of the aluminum in the filter cake was $\mathrm{Al}(\mathrm{OH})_{3}$ precipitate, $\mathrm{NaAl}(\mathrm{OH})_{4}$ precipitate, or $\mathrm{NaAl}(\mathrm{OH})_{4}$ in the residual liquor.

Turbidity results for the dissolved filter cake samples are shown in Table 4-5. Not surprisingly, turbidity increases with increasing $\mathrm{Al}$ concentration in the feed (top to bottom in each column). The decrease in turbidity from left-to-right suggests that (1) no $\mathrm{Al}(\mathrm{OH})_{3}$ is formed by the acid addition (or whatever $\mathrm{Al}(\mathrm{OH})_{3}$ did form was redissolved), and (2) separation of the mother liquor from the filter cake improves with acid addition.

Table 4-5. Filter Cake Sample Turbidity (NTU).

\begin{tabular}{|c|c|c|c|}
\hline IPS & Direct & PN & PNO \\
\hline Group 1 & 122 & 102 & 82 \\
\hline Group 2 & 150 & 128 & 112 \\
\hline Group 3 & 160 & 142 & 140 \\
\hline Group 4 & 170 & 150 & 122 \\
\hline
\end{tabular}

\subsection{HYDROXIDE CONCENTRATION IN FILTRATE}

The concentration of hydroxide ion in the filtrate (Table 4-6) was determined by titration with $\mathrm{HNO}_{3}$. The general increase from top-to-bottom in the "Direct" column is indicative of the increasing hydroxide concentration in the feed. For the PN runs, the total amount of $\mathrm{HNO}_{3}$ added during the evaporation was calculated to keep the final hydroxide concentration above $2.0 \mathrm{M}$ and higher than the final $\mathrm{Al}$ concentration, which was calculated as ranging from $1.2 \mathrm{M}$ for Group 1 to $2.5 \mathrm{M}$ for Group 4. For the PNO runs, the amount of $\mathrm{HNO}_{3}$ was calculated to keep the final hydroxide concentration above $2.0 \mathrm{M}$ and to drive reactions 2 and 4 to $50 \%$ 
completion. The observed hydroxide concentrations for the PNO runs are lower than intended, implying that reactions 2 and 4 did not approach $50 \%$ completion.

Table 4-6. Hydroxide Concentration in Filtrate (M).

\begin{tabular}{|c|c|c|c|}
\hline IPS & Direct & PN & PNO \\
\hline Group 1 & 4.02 & 2.09 & 1.04 \\
\hline Group 2 & 3.84 & 2.20 & 1.18 \\
\hline Group 3 & 4.56 & 2.71 & 1.22 \\
\hline Group 4 & 6.22 & 3.01 & 1.40 \\
\hline
\end{tabular}

\subsection{FILTRATE CONCENTRATIONS OF METALS AND ANIONS}

Filtrate samples from all 12 IPS evaporation tests were submitted for analysis of metals by inductively coupled plasma spectroscopy and for analysis of anions by ion chromatography. Results are summarized in Table 4-7.

In general terms, the top-to-bottom trend for each analyte in Table 4-7 mirrors the changes in concentration in the feed (Table 2-1). Left-to-right trends are a little more scattered. The essential lack of left-to-right trend for $\mathrm{Al}$ is encouraging in that it shows the Al basically unaffected by the acid addition. The downward trend for $\mathrm{Na}$ (left-to-right) reflects the decreasing ionic strength of the filtrate, as noted in Section 4.4. The downward trend for $\mathrm{NO}_{2}$, especially in the last column, indicates that the PNO treatment was successful in oxidizing the nitrite to nitrate but not to the $50 \%$ completion that was hoped for. The increasing trend for $\mathrm{SO}_{4}$ is a little surprising, indicating that sulfate is more soluble in the PN and PNO filtrates than in the untreated (direct) samples. 
RPP-RPT-38985, Rev. 0

Table 4-7. Filtrate Concentrations (molarity) of Metals and Anions.

\begin{tabular}{|c|c|c|c|c|}
\hline Analyte & IPS & Direct & PN & PNO \\
\hline \multirow[t]{4}{*}{$\mathrm{Al}$} & Group 1 & 1.13 & 1.08 & 0.89 \\
\hline & Group 2 & 1.41 & 1.36 & 1.42 \\
\hline & Group 3 & 1.71 & 1.83 & 1.61 \\
\hline & Group 4 & 2.03 & 1.99 & 1.70 \\
\hline \multirow[t]{4}{*}{$\mathrm{Cr}$} & Group 1 & 0.060 & 0.056 & 0.040 \\
\hline & Group 2 & 0.040 & 0.039 & 0.033 \\
\hline & Group 3 & 0.034 & 0.036 & 0.027 \\
\hline & Group 4 & 0.032 & 0.032 & 0.023 \\
\hline \multirow[t]{4}{*}{$\mathrm{K}$} & Group 1 & 0.48 & 0.48 & 0.35 \\
\hline & Group 2 & 0.32 & 0.30 & 0.34 \\
\hline & Group 3 & 0.26 & 0.27 & 0.25 \\
\hline & Group 4 & 0.25 & 0.24 & 0.20 \\
\hline \multirow[t]{4}{*}{$\mathrm{Na}$} & Group 1 & 12.5 & 11.4 & 9.2 \\
\hline & IGroup 2 & 12.6 & 11.0 & 11.1 \\
\hline & Group 3 & 12.5 & 11.7 & 10.7 \\
\hline & Group 4 & 14.1 & 11.5 & 10.2 \\
\hline \multirow[t]{4}{*}{$\mathrm{Cl}$} & Group 1 & 0.25 & 0.23 & 0.17 \\
\hline & Group 2 & 0.25 & 0.36 & 0.43 \\
\hline & Group 3 & 0.35 & 0.36 & 0.36 \\
\hline & Group 4 & 0.36 & 0.34 & 0.32 \\
\hline \multirow[t]{4}{*}{$\mathrm{NO}_{3}$} & Group 1 & 4.26 & 4.79 & 6.09 \\
\hline & IGroup 2 & 3.69 & 3.51 & 4.93 \\
\hline & Group 3 & 3.22 & 3.57 & 5.03 \\
\hline & Group 4 & 3.05 & 3.56 & 4.86 \\
\hline \multirow[t]{4}{*}{$\mathrm{NO}_{2}$} & Group 1 & 3.52 & 3.28 & 1.96 \\
\hline & Group 2 & 4.77 & 3.98 & 3.59 \\
\hline & Group 3 & 4.35 & 4.67 & 3.40 \\
\hline & Group 4 & 4.06 & 4.12 & 2.79 \\
\hline \multirow[t]{4}{*}{$\mathrm{PO}_{4}$} & Group 1 & 0.12 & 0.14 & 0.10 \\
\hline & Group 2 & 0.06 & 0.10 & 0.07 \\
\hline & Group 3 & 0.09 & 0.08 & 0.07 \\
\hline & Group 4 & 0.08 & 0.09 & 0.08 \\
\hline \multirow[t]{4}{*}{$\mathrm{SO}_{4}$} & Group 1 & 0.023 & 0.039 & 0.048 \\
\hline & Group 2 & 0.014 & 0.034 & 0.030 \\
\hline & Group 3 & 0.022 & 0.030 & 0.042 \\
\hline & Group 4 & 0.016 & 0.029 & 0.053 \\
\hline
\end{tabular}




\subsection{CRYSTAL SIZE DISTRIBUTION}

Filter cake samples were taken from all 12 tests for determination of crystal size distribution by sieve analysis. Results are shown in Figure 4-2. "Average Size" is defined as the average of the size of the sieve openings above and below the collected fraction. "Mass Density" is defined as mass of the collected fraction divided by the difference in size between the sieves above and below the collected fraction. "\%Mass Density" is 100 times the mass density for the collected fraction divided by the sum of the mass densities for all fractions.

Figure 4-2. Crystal Size Distribution.
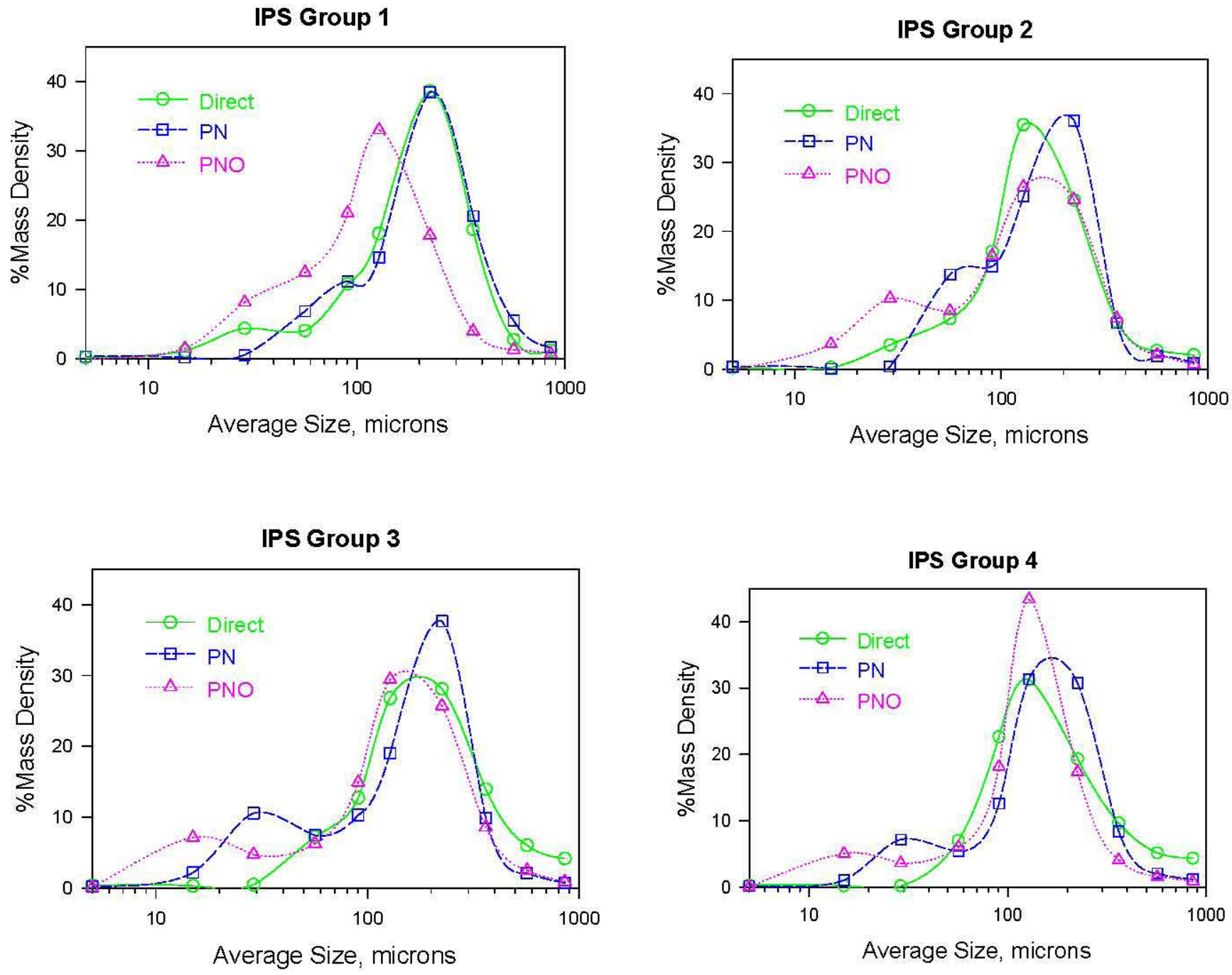

The main differences among the graphs in Figure 4-2 are the apparent decrease in number of very large crystals and an increase in the number of very small crystals in the acid-treated samples. However, examination of the sieve fractions with a polarized light microscope showed that most of the very large particles in the untreated samples were actually agglomerates of smaller crystals. Therefore, the effect of the acid addition was not to make the crystals smaller but to reduce their tendency to agglomerate. 


\section{SUMMARY}

Several conclusions can be drawn from the test results:

a. Increasing $\mathrm{OH}$ and $\mathrm{Al}$ concentrations in the IPS feed solutions lead inevitably to reduced $\mathrm{Na}$ Yield. Without acid treatment, the $\mathrm{Na}$ Yield falls below the $50 \%$ requirement in three out of the four IPS groups tested.

b. Based on filtration times and crystal size distributions, increasing $\mathrm{OH}$ and $\mathrm{Al}$ concentrations have little or no effect on the efficiency of solid/liquid separations. However, the $\% \mathrm{H}_{2} \mathrm{O}$ analyses of the filter cake samples suggest some deleterious effect on the separation. No Cs analyses were performed (in fact, there was no Cs in the feed solutions), so no direct measurements of decontamination factor were possible.

c. Acid addition during evaporation by either the PN or PNO methods increases Na Yield to well above the $50 \%$ requirement by converting some of the $\mathrm{NaOH}, \mathrm{Na}_{2} \mathrm{CO}_{3}$, and $\mathrm{NaNO}_{2}$ into $\mathrm{NaNO}_{3}$.

d. Other interesting effects of the PNO method, which are considered neither advantageous nor detrimental at this point, include reduction of $\mathrm{Cr}$ (VI) to $\mathrm{Cr}$ (III) and an increase in the relative amount of sulfate reporting the high-level waste fraction. 


\section{REFERENCES}

ATS-LT-519-183, Rev. D-0, "ATS Determination of Properties of Radiological Solutions as a Function of Volume Reduction at Reduced Pressure," CH2M HILL Hanford Group, Inc., Richland, Washington.

RHO-CD-1515, 1982, 242-S Evaporator Crystallizer Third Partial Neutralization Campaign, Rockwell Hanford Operations, Richland, Washington.

RPP-34455, 2007, Hanford Medium/Low Curie Waste Pretreatment Alternatives ProjectSubtask 2.1 and Subtask 2.2, Rev. 0, CH2M HILL Hanford Group, Inc., Richland, Washington.

RPP-39091, 2008, Hanford Medium/Low Curie Waste Pretreatment Alternatives ProjectFractional Crystallization Pilot Scale Testing Final Report, Rev. 0, CH2M HILL Hanford Group, Inc., Richland, Washington.

RPP-RPT-31352, 2007, Fractional Crystallization Flowsheet Tests with Actual Tank Waste, Rev. 1, CH2M HILL Hanford Group, Inc., Richland, Washington.

RPP-RPT-33228, 2007, Hanford Medium/Low Curie Waste Pretreatment Alternatives ProjectPhase II Report on Pre-Pilot Work at Swenson Technology, Inc., Rev. 0, CH2M HILL Hanford Group, Inc., Richland, Washington.

RPP-RPT-34136, 2007, Hanford Medium/Low Curie Waste Pretreatment Alternatives ProjectPhase II, Subtask 2.5 and Subtask 2.6, Rev. 0, CH2M HILL Hanford Group, Inc., Richland, Washington.

RPP-RPT-35261, 2007, Fractional Crystallization Laboratory Tests with Simulated Tank Waste, Rev. 0, CH2M HILL Hanford Group, Inc., Richland, Washington. 
RPP-RPT-38985, Rev. 0

APPENDIX A

Boildown Test Data 
Total feed $(\mathrm{mL})$ :

Total feed (g):

$3 \mathrm{M}(8 \mathrm{M}) \mathrm{HNO}_{3}(\mathrm{~mL})$ :

$3 \mathrm{M}(8 \mathrm{M}) \mathrm{HNO}_{3}(\mathrm{~g}):$

Flush $\mathrm{H}_{2} \mathrm{O}(\mathrm{mL})$ :

Condensate $(\mathrm{mL})$ :

Slurry in pot $(\mathrm{g})$ :

Slurry in filter (g):

Accumulation (g):

$\% \mathrm{H}_{2} \mathrm{O}$ in slurry:

Filtration time, (minutes):

Filter cake, measured $(\mathrm{g})$

Filter cake, normalized (g): Fil

\section{filter.}

$\mathrm{Na}$ in cake $(\mathrm{g})$ :

Na Yield (\%):

$\% \mathrm{H}_{2} \mathrm{O}$ in cake $(\%)$ :
Total volume of feed solution, measured by graduated cylinder.

Total mass of feed solution, measured by weighing the feed bottle before and after the evaporation.

Volume of $3 \mathrm{M}$ or $8 \mathrm{M} \mathrm{HNO}_{3}$ added during boildown, measured by graduated cylinder.

Weight of $3 \mathrm{M}$ or $8 \mathrm{M} \mathrm{HNO}_{3}$ added during boildown, calculated by multiplying the measured volume by the respective density ( 1.098 or $1.250 \mathrm{~g} / \mathrm{mL}$, respectively).

Total volume of $\mathrm{H}_{2} \mathrm{O}$ used to flush feed addition line before and after acid additions, measured by graduated cylinder.

Total volume of condensate collected in graduated cylinder.

Mass of slurry remaining in boildown pot at end of evaporation, measured by weighing the pot before the filtration.

Mass of slurry delivered to the filter apparatus, measured by weighing the boildown pot before and after pouring the slurry into the filter.

Mass of material remaining in boildown apparatus, calculated as the difference between the Input and Output, where

$$
\begin{aligned}
& \text { Input }(\mathrm{g})=\mathrm{Feed}+\text { Flush } \mathrm{H}_{2} \mathrm{O}+\mathrm{HNO}_{3} \text { and } \\
& \text { Output }(\mathrm{g})=\text { Condensate }+ \text { Slurry in pot }
\end{aligned}
$$

Percent water is slurry at end of evaporation, measure by oven-drying of slurry samples before filtration.

Length of time required to filter the slurry, beginning when vacuum is applied to the filter apparatus and ending when filtrate collection rate slows to less than $1 \mathrm{drip} / \mathrm{sec}$.

Filter cake, normalized, times 0.279 , based on assumption that all filter cakes contain $27.9 \mathrm{wt} \% \mathrm{Na}$ (average from previous studies).

$\mathrm{Na}$ in cake times 100 divided by $37.0 \mathrm{~g}$ (based on $0.25 \mathrm{~L}$ feed (a) $6.434 \mathrm{M} \mathrm{Na}$ and $23.0 \mathrm{~g} / \mathrm{mol}$ ).

Percent water in filter cake measured by oven-drying of duplicate filter cake samples. 
Filtrate, measured (g): Actual weight of filtrate determined by weighing the filter flask before and after filtering.

Filtrate, normalized (g): Weight of filtrate adjusted to account for loss of slurry as pot residue and $\% \mathrm{H}_{2} \mathrm{O}$ samples; (Filtrate, normalized) $=($ Filtrate, measured) * (total slurry) / (slurry delivered to filter).

Filtrate density $(\mathrm{g} / \mathrm{mL})$ : Actual density of filtrate measured by volumetric flask.

$\% \mathrm{H}_{2} \mathrm{O}$ in filtrate $(\%)$ : $\quad$ Percent water in filtrate measured by oven-drying of duplicate filtrate samples.

Total liquid phase $(\mathrm{g})$ : $\quad$ Used to calculate $\mathrm{OH}$ and $\mathrm{Al}$ concentrations in liquid phase at end of boildown; $($ Total liquid phase $)=($ Filtrate, normalized $)$ $+($ Liquid retained in filter cake); (Liquid retained in cake $)=$ (Cake, normalized $) *\left(\% \mathrm{H}_{2} \mathrm{O}\right.$ in cake $) /\left(\% \mathrm{H}_{2} \mathrm{O}\right.$ in filtrate $)$.

Total liquid phase $(\mathrm{mL}): \quad($ Total liquid phase, $\mathrm{mL})=($ Total liquid phase, $\mathrm{g}) /($ Filtrate density, g/mL).

$[\mathrm{OH}]_{\text {feed }}(\mathrm{M})$ : $\quad$ Concentration of hydroxide in feed solution, determined by feed preparation.

$[\mathrm{OH}]_{\text {filtrate, }}$ calculated $(\mathrm{M})$ : Hydroxide concentration in filtrate calculated as $([\mathrm{OH}] \mathrm{feed})$ * (250)/ (Total liquid phase), where $250 \mathrm{~mL}=$ initial feed volume.

$[\mathrm{OH}]_{\text {filtrate, }}$ measured $(\mathrm{M})$ : Hydroxide concentration in filtrate measured by titration of filtrate sample.

$[\mathrm{Al}]_{\text {feed }}(\mathrm{M})$ : $\quad$ Concentration of aluminate in feed solution, determined by feed preparation.

$[\mathrm{Al}]_{\text {filtrate }}$, calculated $(\mathrm{M}): \quad$ Aluminate concentration in filtrate calculated as ([Al]feed)* (250) / (Total liquid phase), where $250 \mathrm{~mL}=$ initial feed volume.

$[\mathrm{Al}]_{\text {filtrate, }}$ measured $(\mathrm{M})$ : Aluminate concentration in filtrate measured by inductively coupled plasma spectroscopy analysis of filtrate sample. 
RPP-RPT-38985, Rev. 0

Table A-1. Test Data, Direct Evaporation Tests.

\begin{tabular}{|l|l|c|c|c|c|}
\hline \multicolumn{1}{|c|}{ Measurement } & Units & IPS Group 1 & IPS Group 2 & IPS Group 3 & IPS Group 4 \\
\hline Total feed & $\mathrm{mL}$ & 250 & 250 & 250 & 250 \\
\hline Total feed & $\mathrm{g}$ & 322.79 & 321.65 & 320.94 & 319.32 \\
\hline Condensate & $\mathrm{mL}$ & 160 & 158 & 161 & 165 \\
\hline Slurry in pot & $\mathrm{g}$ & 147.75 & 154.12 & 150.08 & 143.80 \\
\hline Slurry in filter & $\mathrm{g}$ & 122.51 & 133.98 & 133.17 & 125.37 \\
\hline Accumulation & $\mathrm{g}$ & 15.04 & 9.53 & 9.86 & 10.52 \\
\hline$\% \mathrm{H}_{2} \mathrm{O}$ in slurry & $\mathrm{wt} \%$ & 70.7 & 68.6 & 67.6 & 67.9 \\
\hline Filtration time & $\mathrm{minute}$ & 1.93 & 2.10 & 2.07 & 2.17 \\
\hline Filter cake, measured & $\mathrm{g}$ & 66.92 & 56.63 & 52.66 & 55.76 \\
\hline Filter cake, normalized & $\mathrm{g}$ & 80.71 & 65.14 & 59.34 & 63.96 \\
\hline $\mathrm{Na}$ in cake & $\mathrm{g}$ & 22.52 & 18.17 & 16.56 & 17.84 \\
\hline $\mathrm{Na} \mathrm{Yield}$ & $\mathrm{wt} \%$ & 60.9 & 49.1 & 44.8 & 48.2 \\
\hline$\% \mathrm{H}_{2} \mathrm{O}$ in cake & $\mathrm{wt} \%$ & 13.1 & 14.9 & 15.9 & 17.0 \\
\hline Filtrate, measured & $\mathrm{g}$ & 55.59 & 77.35 & 80.51 & 69.61 \\
\hline Filtrate, normalized & $\mathrm{g}$ & 67.04 & 88.98 & 90.74 & 79.85 \\
\hline Filtrate density & $\mathrm{g} / \mathrm{mL}$ & 1.541 & 1.549 & 1.560 & 1.599 \\
\hline$\% \mathrm{H}_{2} \mathrm{O}$ in filtrate & $\mathrm{wt} \%$ & 40.9 & 40.6 & 37.2 & 33.2 \\
\hline Total liquid phase & $\mathrm{g}$ & 92.8 & 112.8 & 116.2 & 112.6 \\
\hline Total liquid phase & $\mathrm{mL}$ & 60.2 & 72.8 & 74.5 & 70.4 \\
\hline$[\mathrm{OH}]_{\text {feed }}$ & $\mathrm{M}$ & 1.06 & 1.19 & 1.53 & 1.87 \\
\hline$[\mathrm{OH}]_{\text {filtrate, }}$ calculated & $\mathrm{M}$ & 4.40 & 4.08 & 5.14 & 6.64 \\
\hline$[\mathrm{OH}]_{\text {filtrate, }}$ measured & $\mathrm{M}$ & 4.02 & 3.84 & 4.56 & 6.22 \\
\hline$[\mathrm{Al}]$ feed & $\mathrm{M}$ & 0.32 & 0.50 & 0.64 & 0.69 \\
\hline$[\mathrm{Al}]_{\text {filtrate, }}$ calculated & $\mathrm{M}$ & 1.33 & 1.72 & 2.15 & 2.45 \\
\hline$[\mathrm{Al}]_{\text {filtrate, }}$ measured & $\mathrm{M}$ & 1.13 & 1.41 & 1.71 & 2.03 \\
\hline & & & & & \\
\hline
\end{tabular}


RPP-RPT-38985, Rev. 0

Table A-2. Test Data, Partial Neutralization Tests.

\begin{tabular}{|c|c|c|c|c|c|}
\hline Measurement & Units & IPS Group 1 & IPS Group 2 & IPS Group 3 & IPS Group 4 \\
\hline Total feed & $\mathrm{mL}$ & 250 & 250 & 250 & 250 \\
\hline Total feed & $\mathrm{g}$ & 328.51 & 322.65 & 320.46 & 319.43 \\
\hline $3 \mathrm{MHNO}_{3}$ & $\mathrm{~mL}$ & 45 & 45 & 60 & 85 \\
\hline $3 \mathrm{MHNO}_{3}$ & $\mathrm{~g}$ & 49.4 & 49.4 & 65.9 & 93.3 \\
\hline Flush $\mathrm{H}_{2} \mathrm{O}$ & $\mathrm{mL}$ & 90 & 90 & 90 & 90 \\
\hline Condensate & $\mathrm{mL}$ & 295 & 295 & 314 & 340 \\
\hline Slurry in pot & $\mathrm{g}$ & 152.68 & 160.38 & 154.87 & 153.07 \\
\hline Slurry in filter & $\mathrm{g}$ & 133.57 & 141.57 & 133.93 & 133.59 \\
\hline Accumulation & $\mathrm{g}$ & 20.24 & 6.68 & 7.47 & 9.69 \\
\hline$\% \mathrm{H}_{2} \mathrm{O}$ in slurry & $w t \%$ & 27.5 & 29.7 & 29.1 & 29.1 \\
\hline Filtration time & minute & 2.25 & 2.02 & 2.08 & 2.15 \\
\hline Filter cake, measured & $\mathrm{g}$ & 78.64 & 57.14 & 58.77 & 60.94 \\
\hline Filter cake, normalized & $\mathrm{g}$ & 89.89 & 64.73 & 67.96 & 69.83 \\
\hline $\mathrm{Na}$ in cake & $\mathrm{g}$ & 25.08 & 18.06 & 18.96 & 19.48 \\
\hline $\mathrm{Na}$ Yield & $w t^{0} \%$ & 67.8 & 48.8 & 51.3 & 52.7 \\
\hline$\% \mathrm{H}_{2} \mathrm{O}$ in cake & $\mathrm{wt} \%$ & 13.9 & 11.4 & 11.5 & 11.3 \\
\hline Filtrate, measured & $\mathrm{g}$ & 54.93 & 84.43 & 75.16 & 72.65 \\
\hline Filtrate, normalized & $\mathrm{g}$ & 62.79 & 95.65 & 86.91 & 83.25 \\
\hline Filtrate density & $\mathrm{g} / \mathrm{mL}$ & 1.503 & 1.533 & 1.560 & 1.556 \\
\hline$\% \mathrm{H}_{2} \mathrm{O}$ in filtrate & $\mathrm{wt} \%$ & 41.9 & 41.2 & 35.6 & 40.1 \\
\hline Total liquid phase & $\mathrm{g}$ & 92.6 & 113.6 & 108.8 & 103.0 \\
\hline Total liquid phase & $\mathrm{mL}$ & 61.6 & 74.1 & 69.8 & 66.2 \\
\hline$[\mathrm{OH}]_{\text {feed }}$ & $\mathrm{M}$ & 1.06 & 1.19 & 1.53 & 1.87 \\
\hline$[\mathrm{OH}]_{\text {filtrate, }}$ calculated & $\mathrm{M}$ & 2.11 & 2.19 & 2.90 & 3.21 \\
\hline$[\mathrm{OH}]_{\text {filtrate, }}$, measured & $\mathrm{M}$ & 2.09 & 2.20 & 2.71 & 3.01 \\
\hline [Al]feed & $\mathrm{M}$ & 0.32 & 0.50 & 0.64 & 0.69 \\
\hline$[\mathrm{Al}]_{\text {filtrate, }}$, calculated & $\mathrm{M}$ & 1.30 & 1.69 & 2.29 & 2.61 \\
\hline$[\mathrm{Al}]_{\mathrm{filtrate}}$, measured & $\mathrm{M}$ & 1.08 & 1.36 & 1.83 & 1.99 \\
\hline
\end{tabular}


RPP-RPT-38985, Rev. 0

Table A-3. Test Data, Partial Neutralization with Oxidation Tests.

\begin{tabular}{|l|l|l|l|l|l|}
\hline \multicolumn{1}{|c|}{ Measurement } & Units & IPS Group 1 & IPS Group 2 & IPS Group 3 & IPS Group 4 \\
\hline Total feed & $\mathrm{mL}$ & 250 & 250 & 250 & 250 \\
\hline Total feed & $\mathrm{g}$ & 322.35 & 321.63 & 320.75 & 318.85 \\
\hline $8 \mathrm{M} \mathrm{HNO}_{3}$ & $\mathrm{~mL}$ & 42 & 45 & 50 & 59 \\
\hline $8 \mathrm{M} \mathrm{HNO}_{3}$ & $\mathrm{~g}$ & 52.5 & 56.3 & 62.5 & 73.8 \\
\hline Flush $\mathrm{H}_{2} \mathrm{O}$ & $\mathrm{mL}$ & 0 & 0 & 0 & 0 \\
\hline Condensate & $\mathrm{mL}$ & 179 & 198 & 200 & 212 \\
\hline Slurry in pot & $\mathrm{g}$ & 176.81 & 170.69 & 174.89 & 175.41 \\
\hline Slurry in filter & $\mathrm{g}$ & 160.07 & 152.08 & 144.18 & 158.54 \\
\hline Accumulation & $\mathrm{g}$ & 19.04 & 9.19 & 8.36 & 5.19 \\
\hline$\% \mathrm{H}_{2} \mathrm{O}$ in slurry & $\mathrm{wt} \%$ & 31.0 & 28.8 & 32.0 & 31.9 \\
\hline Filtration time & $\mathrm{minute}$ & 2.10 & 2.50 & 1.43 & 1.70 \\
\hline Filter cake, measured & $\mathrm{g}$ & 78.00 & 76.39 & 60.34 & 67.45 \\
\hline Filter cake, normalized & $\mathrm{g}$ & 86.16 & 85.73 & 73.19 & 74.62 \\
\hline $\mathrm{Na}$ in cake & $\mathrm{g}$ & 24.04 & 23.92 & 20.42 & 20.82 \\
\hline $\mathrm{Na} \mathrm{Yield}$ & $\mathrm{wt} \%$ & 65.0 & 64.7 & 55.2 & 56.3 \\
\hline$\% \mathrm{H}_{2} \mathrm{O}$ in cake & $\mathrm{wt} \%$ & 11.1 & 11.1 & 13.0 & 11.5 \\
\hline Filtrate, measured & $\mathrm{g}$ & 82.07 & 75.69 & 83.84 & 91.09 \\
\hline Filtrate, normalized & $\mathrm{g}$ & 90.65 & 84.95 & 101.70 & 100.79 \\
\hline Filtrate density & $\mathrm{g} / \mathrm{mL}$ & 1.493 & 1.518 & 1.520 & 1.516 \\
\hline$\% \mathrm{H}_{2} \mathrm{O}$ in filtrate & $\mathrm{wt} \%$ & 43.8 & 41.4 & 41.8 & 42.7 \\
\hline Total liquid phase & $\mathrm{g}$ & 112.4 & 107.9 & 124.5 & 120.9 \\
\hline Total liquid phase & $\mathrm{mL}$ & 75.3 & 71.1 & 81.9 & 79.8 \\
\hline$[\mathrm{OH}]_{\text {feed }}$ & $\mathrm{M}$ & 1.06 & 1.19 & 1.53 & 1.87 \\
\hline$[\mathrm{OH}]_{\text {filtrate }}$ measured & $\mathrm{M}$ & 1.04 & 1.18 & 1.22 & 1.40 \\
\hline$[\mathrm{Al}]$ feed & $\mathrm{M}$ & 0.32 & 0.50 & 0.64 & 0.69 \\
\hline$[\mathrm{Al}]_{\text {filtrate, }}$ calculated & $\mathrm{M}$ & 1.06 & 1.76 & 1.95 & 2.16 \\
\hline$[\mathrm{Al}]_{\text {filtrate, }}$ measured & $\mathrm{M}$ & 0.89 & 1.42 & 1.61 & 1.70 \\
\hline & & & & & \\
\hline
\end{tabular}

